\title{
Effect of Pentoxifylline on Antioxidant Status of Healthy and Endotoxemic New Zealand White Rabbits
}

\author{
E. KESKIN ${ }^{1}$, E. OZTEKIN (MENEVSE) ${ }^{2}$, R. COL1, A. SIVRIKAYA ${ }^{2}$, K. UNEY3, E. YAZAR ${ }^{3 *}$ \\ ${ }^{1}$ Department of Physiology, Faculty of Veterinary Medicine, \\ ${ }^{2}$ Department of Biochemistry, Faculty of Meram Medicine, \\ ${ }^{*}$ Department of Pharmacology and Toxicology, Faculty of Veterinary Medicine, \\ University of Selcuk, Konya, Turkey \\ Received December 16, 2003 \\ Accepted March 3, 2005
}

\begin{abstract}
Keskin E., E. Oztekin (Menevse), R. Col, A. Sivrikaya, K. Uney, E. Yazar: Effect of Pentoxifylline on Antioxidant Status of Healthy and Endotoxemic New Zealand White Rabbits. Acta Vet. Brno 2005, 74: 17-21.

In this study, effect of pentoxifylline on antioxidant status of healthy and endotoxemic rabbits was investigated. Endotoxemia was induced with $E$. coli lipopolysaccharide in New Zealand white rabbits. Forty rabbits were randomly divided into four equal groups. Group 1 served as control. Animals in Group 2 were given lipopolysaccharide $(400 \mu \mathrm{g} / \mathrm{kg})$ intravenously, in Group 3 pentoxifylline $(50 \mathrm{mg} / \mathrm{kg})$ was injected intraperitoneally. In Group 4; pentoxifylline $(50 \mathrm{mg} / \mathrm{kg}$ intraperitoneally) and lipopolysaccharide (400 $\mu \mathrm{g} / \mathrm{kg}$, intravenously) were injected simultaneously. Animals were killed, and liver, heart and kidney samples were taken at 6 hours after administrations. Malondialdehyde, superoxide dismutase, glutathione peroxidase and reduced glutathione levels of heart, liver and kidney tissues were measured. Lipopolysaccharide caused significant increases $(p<0.05)$ in hepatic malondialdehyde, and cardiac, hepatic and renal glutathione peroxidase activities. It however, caused significant $(p<0.05)$ decrease in hepatic superoxide dismutase activity when compared to control group. Pentoxifylline caused significant $(p<0.05)$ increases of cardiac and hepatic malondialdehyde levels, cardiac superoxide dismutase and renal glutathione peroxidase activities, and cardiac, hepatic and renal reduced glutathione levels when compared to control group. As a result, pentoxifylline has no exactly beneficial effect on the antioxidant status of healthy and endotoxaemic New Zealand white rabbits at the administered dose and route. Although it was stated that pentoxifylline may be beneficial in endotoxaemia, its antioxidant effect may be dependent on dose, administration route and animal species. For this reason, when pentoxifylline is used in endotoxaemia, a treatment protocol should be done for each animal species.
\end{abstract}

Pentoxifylline, lipopolysaccharide, antioxidant status, rabbits

Lipopolysaccharide (LPS), a major component of the outer membranes of gram (-) bacteria, is released during infection and induces a number of pathological reactions leading to cardiovascular failure and damage to numerous organs. LPS can elicit a systemic inflammatory response syndrome defined as sepsis. When sepsis is accompanied by hypotension plus organ dysfunction, the condition is known as septic shock and the mortality of animals in septic shock has remained high. The common mechanism of tissues damage in the septic shock may be related to widespread vascular endothelial injury and microthrombosis. Homeostasis fails and dysfunction of major organs (heart, kidney, liver) may occur (Hardaway 2000; Cadenas and Cadenas 2002).

There is convincing evidence of severe oxidative stress in sepsis. Oxidative stress occurs when antioxidant balance is disrupted by excessive production of reactive oxygen species (ROS) such as superoxide radical, hydroxyl radical, hydrogen peroxide, singlet oxygen and/or by inadequate antioxidant defense mechanisms such as superoxide dismutase (SOD)

\footnotetext{
Address for correspondence:

Dr. Enver Yazar

Department of Pharmacology and Toxicology

Faculty of Veterinary Medicine

University of Selcuk

42031, kampus Konya, Turkey
}

Phone: +903322 410041

Fax: +903322410063

e-mail: eyazar@selcuk.edu.tr

http://www.vfu.cz/acta-vet/actavet.htm 
and glutathione peroxidase (GPX) may occur in sepsis (Macdonald et al. 2003). ROS constitute a major part of biologically important free radicals (Toyokuni 1999; Suzzocrea et al. 2001). There is a large amount of evidence to show that the production of ROS occurs at the site of inflammation/infection and contributes to tissue damage (Cnubben et al. 2001; Suzzocrea et al. 2001) and current knowledge indicates that free radical damage plays a key role in LPS-induced septic shock (Ben-Shaul et al. 2001; Cadenas and Cadenas 2002). Recently, a potential role of superoxide radical in septic shock has been identified (Salvemini and Cuzzocrea 2002).

Oxidative stress can be prevented by the action of enzymatic and chemical antioxidant defenses in the body. The enzyme that provides the first line of defense against ROS damage (Cnubben et al. 2001). SOD catalyses two molecules of superoxide to hydrogen peroxide and molecular oxygen, however, it is source of cellular hydrogen peroxide (Nordberg and Arner 2001). GPX plays a critical role in the defense against oxidative stress (Dringen 2000; Cnubben et al. 2001), it catalyses the reduction of hydrogen peroxide or lipid peroxides with reduced glutathione (GSH) (Chan and Decker 1994). When antioxidant capacity is not sufficient against to ROS, lipid peroxidation occurs in the cell. Malondialdehyde (MDA) is formed during the lipid peroxidation (Valenzuela 1991) and it is accepted as a marker of lipid peroxidation (Macdonald et al. 2003).

Pentoxifylline (PTX) is a phosphodiesterase inhibitor that inhibits TNF $\alpha$ release and neurophil adhesiveness and degranulation. In endotoxemic animal, PTX improves tissue oxygen extraction capabilities (Vincent 1997; Hanna 2003). It is stated that PTX may be beneficial in endotoxemia (Krysztopik et al. 2000).

In the present study, SOD and GPX activities were measured as antioxidant enzymes, MDA was measured as a marker of lipid peroxidation and GSH was determined as well in the heart, liver and kidney. Liver was selected because it is one of the tissues showing a high rate of free radical generation, and the kidney is the body's most important organ of excretion and homeostasis and it is a frequent target for a variety of toxic agents due to its metabolic capacity for concentrating toxicants and/or metabolites during the excretory process (Pfaller et al. 1990; Perez-Campo et al. 1993). Heart is the main organ of circulatory system and depressed by $\beta$-endorphins in shock (Kay a 1997). The aim of this study was to investigate the possible protective effect of pentoxifylline as on antioxidant status in healthy and endotoxemic New Zealand white rabbits.

\section{Materials and Methods}

The study was carried out on 40 male New Zealand white rabbits aged 8-10 months and weighing 2-2.5 kg. The animals were reared at Selcuk University Experimental Medicine Research and Application Centre (Konya, Turkey). Animals were fed standard pellet diet and tap water ad libitum. Ethical Committee of the Faculty of Veterinary Medicine (report No. 2004/03) approved the study protocol.

Study groups were formed as follows:

Group 1: control with no treatment

Group 2: the animals were injected LPS $(400 \mu \mathrm{g} / \mathrm{kg}$ ) intravenously (Escherichia coli LPS 0111;B4, Sigma, auricular vein).

Group 3: the animals were injected PTX $(50 \mathrm{mg} / \mathrm{kg})$ intraperitoneally (Trental ${ }^{\circledR}$ amp, Hoechst Marion Roussel, Istanbul, Turkey).

Group 4: the animals were injected PTX (50 mg/kg, intraperitoneally) and LPS (400 $\mu \mathrm{g} / \mathrm{kg}$, intravenously) simultaneously.

All rabbits were killed (Nembutal, $60 \mathrm{mg} \cdot \mathrm{kg}^{-1}$ i.v.) and tissue samples (liver, heart and kidney) were collected at 6 hours after treatments. Samples were stored $-80{ }^{\circ} \mathrm{C}$ until analyses.

MDA (Mihara and Uchiyama 1978) and GSH (Ellman 1959) levels of tissues were determined by previously reported spectrometric (Shimadzu UV-1601, Japan) methods. SOD (Randox-Ransod, 125), GPX (Randox-Ransel, 505) and total protein level (Sigma) were measured commercially available kits with spectrophotometer.

All values are expressed as mean \pm SE. The results were analyzed by Tukey multiple range test (SPSS for windows, release 6.0 ). In all cases, probability of error of less than 0.05 was selected as the criterion for statistical significance. 


\section{Results and Discussion}

Effect of pentoxifylline on malondialdehyde, superoxide dismutase, glutathione peroxidase and reduced glutathione levels of tissues in healthy and endotoxemic New Zealand rabbits is given in Table 1.

Table 1. Effect of pentoxifylline on malondialdehyde, superoxide dismutase, glutathione peroxidase and glutathione levels in healthy and endotoxemic rabbits (mean $\pm \mathrm{SE}$ )

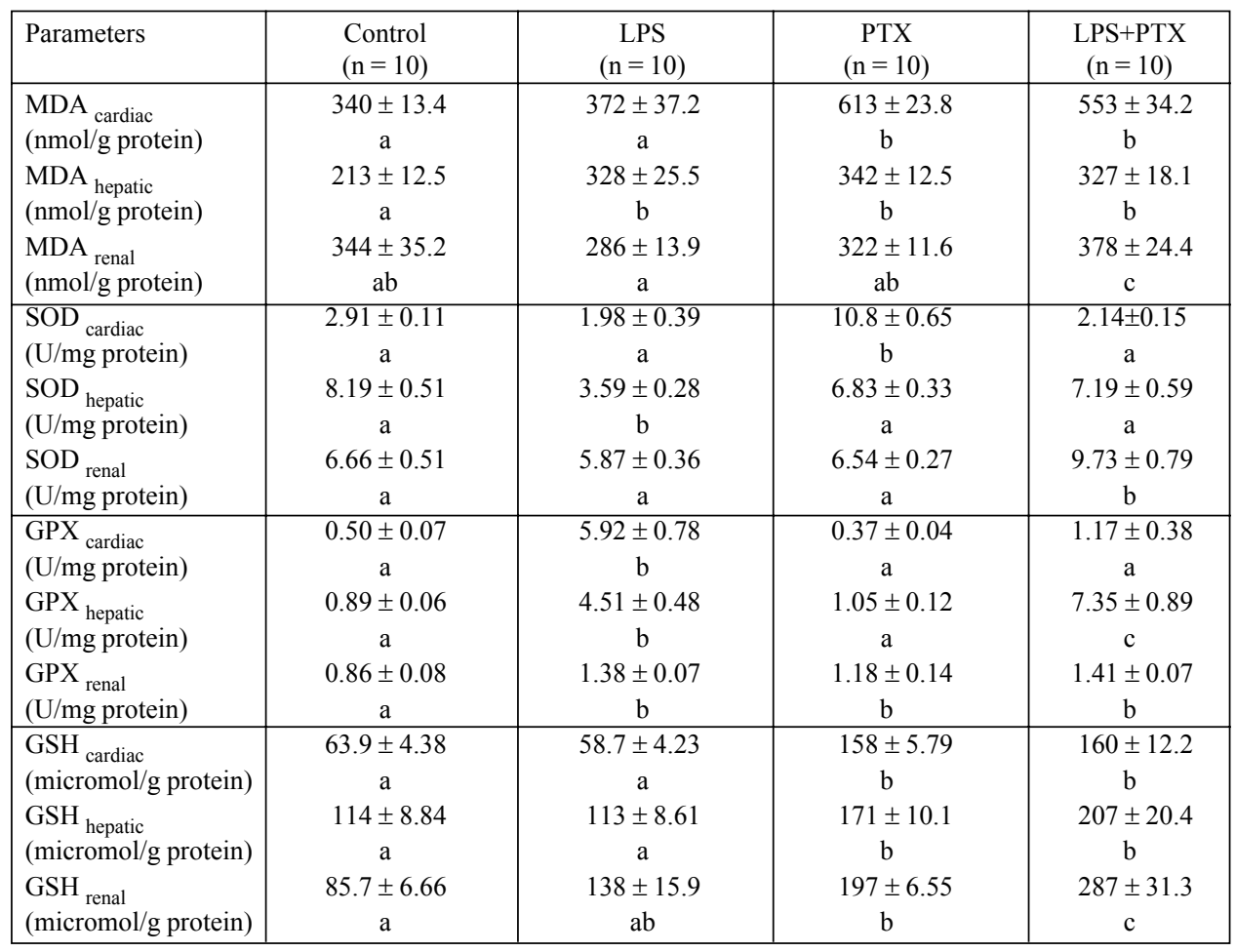

$\mathrm{a}, \mathrm{b}, \mathrm{c}$; Different letters in the same row is statistically significant $(p<0.05)$. PTX, pentoxifylline; LPS, lipopolysaccharide; MDA, malondialdehyde; SOD, superoxide dismutase; GPX, glutathione peroxidase; GSH, reduced glutathione.

Studies reported so far that were related to effect of LPS on antioxidant status yielded controversial results. In the present study, LPS increased hepatic MDA, and cardiac, hepatic and renal GPX levels. On the other hand, it decreased hepatic SOD activity. It was stated that LPS increased MDA levels of heart, plasma (Ben-Shaul et al. 2001; Altavilla et al. 2002), brain (Kheir-Eldin et al. 2001; Abd El-Gawad and Khalifa 2001) and diaphragm (Arias-Diaz et al. 1997). In addition to these, it was reported that LPS increased GPX activity of brain (Abd El-Gawad and Khalifa 2001) and decreased SOD activity of macrophages (Joe and Lokesh 1997). These data are agreement with our results. On the contrary, it was reported that LPS increased hepatic Mn-SOD (Portoles et al. 1996), cardiac SOD activities (Ben-Shaul et al. 2001), and decreased GPX activity of hepatocytes (Catala and Portoles 2002).

In PTX-treated group, PTX caused significant increases of MDA levels in liver and heart, 
GSH levels of all tissue samples, SOD activity of heart and GPX activity of kidney when compared to control group. On the other hand, when LPS and PTX were administered simultaneously, PTX had no protective antioxidant effect. In this study, LPS+PTX increased MDA and GSH levels of all tissues, and renal SOD and GPX activities, and hepatic GPX activity. It was reported that PTX increased liver MDA, SOD, GPX levels in ischemia/reperfusion (Demir and Inal-Erden 1998). Contrary to this result, it was reported that LPS increased MDA level of diaphragm and PTX prevented this increases (Arias-Diaz et al. 1997), and PTX decreased tissue MDA levels in rats after skin ulceration induced by adriamycin (Bekerecioglu et al. 1998).

It was stated that PTX might be beneficial in endotoxaemia (Kry sztopik et al. 2000) and PTX increased the survival time in severe endotoxaemia of rats (Wu et al. 1999). However, it was stated that PTX did not have significant antioxidant capacity at therapeutic concentrations, but increasing their concentrations led to a significant scavenger effect in humans (Horvath et al. 2002). As a result, PTX may be beneficial in endotoxaemia, but its antioxidant effect may be depend on dose, administration route and animal species. For this reason, when PTX is used in endotoxemia, treatment protocol should be done for each animal species.

\section{Účinek pentoxifyllinu na stav antioxidantů u zdravých a endotoxemických bílých novozélandských králíků}

V této studii byl zjištován účinek pentoxifyllinu na stav antioxidantů u zdravých a endotoxemických bílých novozélandských králíků. Endotoxemie byla vyvolána lipopolysacharidem E. coli. 40 králíků bylo náhodně rozděleno do 4 stejných skupin. Skupina 1 sloužila jako kontrolní. Skupině 2 bylo aplikováno $400 \mu \mathrm{g} \cdot \mathrm{kg}^{-1}$ lipopolysacharidu i.v. Skupině 3 byl aplikován pentoxifyllin v dávce $50 \mathrm{mg} \cdot \mathrm{kg}^{-1}$ intraperitoneálně. Skupině 4 byl aplikován zároveň pentoxifylin v dávce $50 \mathrm{mg} \cdot \mathrm{kg}^{-1}$ intraperitoneálně a lipopolysacharid v dávce $400 \mu \mathrm{g} \cdot \mathrm{kg}^{-1}$ i.v. Zvírata byla utracena $6 \mathrm{~h}$ po aplikaci a byly jim odebrány vzorky jater, srdce a ledvin. Bylo měřeno množství malondialdehydu, superoxiddismutázy, glutathionperoxidázy $\mathrm{v}$ játrech, srdci a ledvinách. Ve srovnání s kontrolní skupinou způsobil Lipopolysacharid statisticky významné zvýšení jaterního malondialdehydu $(p<0,05)$, statisticky významný vzrůst aktivity glutathionperoxidázy v srdci, játrech a ledvinách $(p<$ 0,05), nicméně zpo̊sobil též statisticky významné zvýšení aktivity jaterní superoxiddismutázy $(p<0,05)$. Ve srovnání s kontrolní skupinou způsobil pentoxifyllin satisticky významné $(p<0,05)$ zvýšení koncentrace malondialdehydu, aktivity superoxiddismutázy $\mathrm{v}$ krvi a redukovaného glutathionu $\mathrm{v}$ játrech a ledvinách. $Z$ výsledků vyplývá, že pentoxifylin nemá vysloveně kladný účinek na stav antioxidantů u zdravých a endotoxemických bílých novozélandských králíků v podané dávce a způsobu podání. I když pentoxifyllin mủže být prospěšný při endotoxemii, jeho účinek může záviset na dávce, způsobu podání a druhu zviřrete. Proto by se měl při léčbě endotoxemií pentoxifyllinem vypracovat protokol léčby pro každý druh zvířat zvlášt́.

\section{Acknowledgement}

This study was supported SUBAPK (2002/205)

\section{References}

ABD EL-GAWAD, HM, KHALIFA, AE 2001: Quercetin, coenzyme Q10, and L-canavanine as protective agents lipid peroxidation and nitric oxide generation in endotoxin-induced shock in rat brain. Pharmacol Res 43: 257-263

ALTAVILlA, D, SQUADRITO, G, MINUTOLI, L, DEODATO, B, BOVA, A, SARDELLA, A, SEMINARA, P, PASSANITI, M, URNA, G, VENUTI, SF, CAPUTI, AP, SQUADRITO, F 2002: Inhibition of nuclear factor$\mathrm{kB}$ activation by IRFI 042, protects against endotoxin-induced shock. Cardiovasc Res 54: 684-693 
ARIAS-DIAZ, J, VARA, E, TORRES-MELERO, J, GARCIA, C, HERNANDEZ, J, BALIBREA, JL 1997: Local production of oxygen free radicals and nitric oxide in rat diaphragm during sepsis: Effects of pentoxifylline and somatostatin. Eur J Surg 163: 619-625

BEKERECIOGLU, M, KUTLUHAN, A, DEMIRTAS, I, KARAAYVAZ, M 1998: Prevention of adriamycininduced skin necrosis with various free radical scavengers. J Surg Res 75: 61-65

BEN-SHAUL, V, LOMNITSKI, L, NYSKA, A, ZUROVSKY, Y, BERGMAN, M, GROSSMAN, S 2001: The effect of natural antioxidants, NAO and apomycin, on oxidative stress in the rat hear following LPS challenge. Toxicol Lett 123: 1-10

CADENAS, S, CADENAS, AM 2002: Fighting the stranger-antioxidant protection against endotoxin toxicity. Toxicology 180: 45-63

CATALA, M, PORTOLES, MT 2002: Action of E. coli endotoxin, IL-1 $\beta$ and TNF- $\alpha$ on antioxidant status of cultured hepatocytes. Mol Cell Biochem 231:75-82

CHAN, KM, DECKER, EA 1994: Endogenous skeletal muscle antioxidants. Crit Rev Food Sci Nutr 34: 403-426

CNUBBEN, NHP, RIETJENS, IMCM, WORTELBOER, H, VAN-ZANDEN, J, VAN BLADEREN, PJ 2001: The interplay of glutathione related processes in antioxidant defense. Environ Toxicol Pharmacol 10: 141-152

DEMIR, S, INAL-ERDEN, M 1998: Pentoxifylline and N-acetylcystein in hepatic ischemia/reperfusion injury. Clin Chim Acta 275: 127-135

DRINGEN, R 2000: Metabolism and functions of glutathione in brain. Prog Neurobiol 62: 649-641

ELLMANN, GL 1959: Tissue sulfhydryl groups. Arch Biochem Biophys 82: 70-77

HANNA, NF 2003: Sepsis and septic shock. Top Emerg Med 25: 158-165

HARDAWAY, RM 2000: A review of septic shock. Am Surg 66: 22-29

HORVATH, B, MARTON, R, HALMOSI, R, ALEXY, T, SZAPARY, L, VEKASI, J, BIRO, Z, HABON, T, KESMARKY, G, TOTH, K 2002: In vitro antioxidant properties of pentoxifylline, piracetam, and vinpocetine. Clin Neuropharmacol 25: 37-42

JOE, B, LOKESH, BR 1997: Studies on the inactivation of superoxide dismutase activity by nitric oxide from rat peritoneal macrophages. Mol Cell Biochem 168: 87-93

KAYA, S 1997: Circulatory shock and treatment. In: KAYA, S, PIRINCCI, I, BILGILI, A (Eds).: Veterinary Applied Pharmacology. Volume 2, Medisan, Ankara, pp. 147-152

KHEIR-ELDIN, AA, MOTAWI, TK, GAD, MZ, ABD-ELGAWAD, HM 2001: Protective effect of vitamin E, $\beta$-carotene and $n$-acetylcysteine from the brain oxidative stress induced in rats by lipopolysaccharide. Int J Biochem Cell Biol 33: 475-482

KRYSZTOPIK, RJ, MATHESON, PJ, SPAIN, DA, GARRISON, RN, WILSON, MA 2000: Lazaroid and pentoxifylline suppress sepsis-induced increases in renal vascular resistance via altered arachidonic acid metabolism. J Surg Res 93: 75-81

MACDONALD, J, GALLEY, HF, WEBSTER, NR 2003: Oxidative stress and gene expression in sepsis. Br J Anaest $90: 221-232$

MIHARA, M, UCHIYAMA, M 1978: Determination of malonaldehyde precursor in tissues by thiobarbituric acid test. Anal Biochem 86: 271-278

NORDBERG, J, ARNER, ESJ 2001: Reactive oxygen species, antioxidants, and the mammalian thioredoxin system. Free Radic Biol Med 31: 1287-1312

PEREZ-CAMPO, R, LOPEZ-TORRES, M, ROJAS, C, CADENAS, S, BARJA, G 1993: A comparative study of free radicals in vertebrates-I. Antioxidant enzymes. Comp Biochem Physiol 105: 749-755

PFALLER, W, GSTRAUNTHALER, G, WILLINGER, CC 1990: Morphology of renal tubular damage from nephrotoxins. Toxicol Lett 53: 39-43

PORTOLES, MT, CATALA, M, ANTON, A, PAGANI, R 1996: Hepatic response to the oxidative stress induced by $E$. coli endotoxin: Glutathione as an index of the acute phase during the endotoxic shock. Mol Cell Biochem 159: $115-121$

SALVEMINI, D, CUZZOCREA, S 2002: Oxidative stress in septic shock and disseminated intravascular coagulation. Free Radic Biol Med 33: 1173-1185

SUZZOCREA, S, RILEY, DP, CAPUTI, AP, SALVEMINI, D 2001: Antioxidant therapy: A new pharmacological approach in shock, inflammation, and ischemia/reperfusion injury. Pharmacol Rev 53: 135-159

TOYOKUNI, S 1999: Reactive oxygen species induced molecular damage and its application in pathology. Pathol Int 49: 91-102

WU, CC, LIAO, MH, CHEN, SJ, YEN, MH 1999: Pentoxifylline improves circulatory failure and survival in murine models of endotoxemia. Eur J Pharmacol 373: 41-49

VALENZUELA, A 1991: The biological significance of malondialdehyde determination in the assessment of tissue oxidative stress. Life Sci 48: 301-309

VINCENT, JL 1997: New therapies in sepsis. Chest 112: 330-338 